\title{
PENERAPAN SANKSI PIDANA TERHADAP ANAK PELAKU TINDAK PIDANA
}

\author{
Krismiyarsi"
}

ABSTRACT

The type of crime that can be applied to the offender's offender is regulated in Article 71 of the Child Criminal Justice System Act, namely principal and additional criminal penalties. The principal crimes consist of criminal warnings, criminal conditions (coaching outside the institution, community service; or supervision), job training, coaching in institutions, and prisons. Additional penalties consist of: Deprivation of profits obtained from criminal acts or fulfillment of customary obligations. This is intended to provide an opportunity for the judge to choose which criminal is suitable for the child in the case he is handling. In practice, judges do not always impose criminal offenses similar to the types of criminal acts listed in the material criminal law in accordance with the article which are violated by the offender's offender, even the judge is not bound by the prosecutor's demands. The judge has the freedom to impose a criminal in accordance with his conscience. In addition to being influenced by juridical considerations, judges' decisions are also non-judicial considerations, namely the sociological, psychological, ethical, and historical aspects of the child.

\section{Keywords : the application of criminal sanctions, child criminal perpetrators}

\section{PENDAHULUAN}

Menurut Pasal 28 Undang-undang Dasar 1945, setiap anak berhak atas kelangsungan hidup, tumbuh dan berkembang serta berhak atas perlindungan dari kekerasan dan diskriminasi.

Anak sebagai bagian dari generasi muda merupakan penerus cita-cita perjuangan bangsa dan sumber daya manusia bagi pembangunan nasional. Oleh karenanya diperlukan pembinaan secara terus menerus demi kelangsungan hidup, pertumbuhan dan perkembangan fisik, mental, dan sosial serta perlindungan dari segala kemungkinan yang akan mem bahayakan mereka dan bangsa di masa depan, Upaya pembinaan dan perlindungan

\footnotetext{
* Krismiyarsi adalah Pengajar di Fakultas Hukum UNTAG Semarang, Bidang Kajian Hukum Pidana dapat dihubungi melalui Email: Krismiyarsi@yahoo.com
}

tersebut dihadapkan pada berbagai permasalahan dalam masyarakat. Bahkan anak sebagai obyek dalam perlindungan tersebut, justeru seringkali melakukan perbuatan-perbuatan yang melanggar hukum. Penyimpangan perilaku atau perbuatan melanggar hukum ini meng akibatkan anak berurusan dengan hukum, apabila melanggar hukum pidana maka, terhadap anak, akan dikenakan sanksi pidana.

Komisi Perlindungan Anak Indonesia (KPAI), menangani 1.885 kasus pada semester pertama 2018. Dari angka itu, anak berhadapan dengan hukum $(\mathrm{ABH})$ seperti jadi pelaku narkoba, mencuri, hingga asusila menjadi kasus yang paling banyak. Data KPAI menyebut ada 504 kasus ABH, Ketua KPAI Susanto, dalam diskusi di Jalan Wahid Hasim, Jakarta Pusat, Senin (23/7/2018), mengatakan: Dari data tahun 2011 sampai saat ini, $\mathrm{ABH}$ 
menempati posisi paling tinggi.Dalam kasus $\mathrm{ABH}$, kebanyakan anak masuk Lembaga Pemasyarakatan Khusus Anak (LPKA) karena mencuri sebanyak 23,9 persen. Selanjutnya, kasus narkoba 17,8 persen, kasus asusila 13,2 persen dan lainnya.

Berlakunya Undang-undang No. 11 Tahun 2012 tentang Sistem Peradilan Pidana Anak, mencabut berlakunya Undang-undang No. 3 Tahun 1997. Undang-undang ini mulai berlaku setelah 2 (dua) tahun terhitung sejak tanggal diundangkan, sehingga baru berlaku bulan Juli Tahun 2014. Dalam Undang-undang sistem peradilan pidana anak yang baru ini (Undang-undang No. 11 Tahun 2012), terdapat beberapa hal baru yang tidak diatur oleh undang-undang yang lama (Undangundang No. 3 Tahun 1997), diantaranya: mengenai jenis sanksi pidana yang dapat dijatuhkan terhadap anak yang melakukan tindak pidana. Hal ini diatur dalam

Pasal 71, yang terdiri dari :Pidana pokok:

a. Pidana peringatan;

b. Pidana dengan syarat:

1) Pembinaan di luar lembaga;

2) Pelayanan masyarakat; atau

3) Pengawasan.

c. Pelatihan kerja;

d. Pembinaan dalam lembaga; dan

e. Penjara.

Pidana tambahan:

1) Perampasan keuntungan yang diperoleh dari tindak pidana; atau

2) Pemenuhan kewajiban adat.

Banyaknya jenis pidana yang terdapat dalam Pasal 71 Undang-undang Sistem Peradilan Pidana Anak ini, memberi kesempatan kepada hakim untuk memilih mana pidana yang cocok untuk anak dalam kasus yang ditanganinya. Dalam praktiknya hakim tidak selalu menjatuhkan pidana

1 https://news.detik.com/berita/d-4128703/ada504-kasus-anak-jadi-pelaku-pidana-kpaisoroti-pengawasan-ortu, diakses tanggal 5 April 2019. sesuai dengan jenis pidana yang tercantum dalam pasal yang dilanggar oleh anak pelaku tindak pidana, bahkan hakim tidak terikat pada tuntutan jaksa. Hakim memiliki kebebasan dalam menjatuhkan pidana sesuai dengan hati nuraninya. Hal ini dapat ditunjukkan dalam beberapa kasus yang penulis bahas dalam tulisan ini.

\section{Perumusan Masalah}

Berdasarkan latar belakang masalah tersebut di atas kiranya perlu dibahas mengenai: (1) Bagaimana penerapan sanksi pidanaterhadap anak pelaku tindak pidana? (2) Apa yang menjadi pertimbangan hakim dalam menerapkan sanksi pidana terhadap anak pelaku tindak pidana?

\section{Metode Penelitian}

Penelitian ini menggunakan tipe penelitian yuridis normatif, dengan metode pendekatan Undang-Undang, pendekatan kasus, pendekatan konseptual dan pendekatan komparatif.

Pendekatan Undang-Undang dilaku kan dengan menelaah Undang-Undang dan regulasi untuk mencari konsistensi dan kesesuaian antara Undang-Undang yang satu dengan yang lain.

Pendekatan kasus dilakukan dengan cara melakukan telaah terhadap kasuskasus yang berkaitan dengan masalah yang diteliti dan telah memiliki kekuatan hukum tetap, yang menjadi kajian dalam pendekatan kasus adalah selain putusan yang dijatuhkan hakim, juga rasio decidendi atau reasoning yaitu pertimbang an hakim untuk sampai pada suatu putusan.

Pendekatan konseptual beranjak dari pandangan-pandangan doktrin-doktrin yang berkembang di dalam ilmu hukum.

Menurut Peter Mahmud, studi perbandingan hukum merupakan kegiatan untuk membandingkan hukum suatu 
Negara dengan hukum Negara lain atau hukum dari suatu waktu tertentu dengan hukum dari waktu yang lain. Di samping itu juga membandingkan suatu putusan pengadilan yang satu dengan putusan pengadilan lainnya untuk masalah yang sama. Kegiatan ini bermanfaat bagi penyingkapan latar belakang terjadinya ketentuan hukum tertentu untuk masalah yang sama dari dua Negara atau lebih. Penyingkapan ini dapat dijadikan rekomendasi bagi penyusunan atau perubahan perundang-undangan. ${ }^{2}$

Penerapan sanksi pidana atau pemberian pidana, menurut Sudarto mempunyai dua arti:

a. Dalam arti umum ialah yang menyangkut pembentuk UndangUndang, ialah yang menetapkan stelsel sanksi hokum pidana (pemberian pidana in abstracto)

b. Dalam arti konkrit, ialah yang menyangkut berbagai badan atau jawatan yang kesemuanya mendukung dan melaksanakan stelsel sanksi hokum pidana itu. $^{3}$

Dalam penelitian ini yang dimaksud dengan penerapan sanksi pidana adalah pemberian pidana dalam arti konkrit, yaitu penerapan sanksi pidana atau pemberian pidana oleh hakim.

Hal-hal yang dipertimbangkan hakim sebelum memutuskan suatu perkara adalah:

a. Keputusan mengenai peristiwanya, ialah apakah terdakwa telah melakukan perbuatan yang dituduhkan kepadanya, dan kemudian

b. Keputusan mengenai hukumnya, ialah apakah perbuatan yang dilakukan terdakwa itu merupakan suatu tindak pidana dan apakah terdakwa bersalah

2 Peter Mahmud Marzuki, 2006, Penelitian Hukum,Jakarta: Kencana Prenada Media Group, hlm.132.

3 Sudarto, 1983, Hukum dan Hukum Pidana, Bandung: Alumni, hlm.50. dan dapat dipidana, dan akhirnya

c. Keputusan mengenai pidananya apabila terdakwa memang dapat dipidana. ${ }^{4}$

Selanjutnya Sudarto menambah kan: Hakim mempunyai kebebasan untuk menetapkan jenis pidana, cara pelaksanaan pidana dan tinggi rendahnya pidana. Mengenai yang terakhir ini hakim dapat bergerak antara minimum pidana yang umum yang berlaku untuk semua delik dan maksimum pidana yang khusus untuk tiaptiap delik. Namun kebebasan ini tidak berarti bahwa hakim boleh menjatuhkan pidana menurut seleranya sendiri, tanpa ukuran tertentu. Dalam keputusan hakim harus terbaca proses pemikiran yang dapat diikuti oleh orang lain, sehingga wajar apabila diharapkan bahwa dalam pemberian pidana inipun proses pemikiran nya harus dapat diikuti oleh orang lain pula, khususnya oleh terdakwa, orang yang paling berkepentingan dalam proses pemeriksaan perkara itu. ${ }^{5}$

Dalam masalah pemberian pidana ini terdapat pertentangan antara dua aliran dalam hokum pidana ialah aliran klassik dan aliran modern. Aliran klassik melihat terutama kepada perbuatan yang dilakukan dan menghendaki pidana yang dijatuhkan itu seimbang dengan perbuatan tersebut, sedang aliran modern pertama-tama meninjau pembuatnya dan menghendaki individualisasi dari pidana, artinya dalam pemidanaan memperhatikan sifat-sifat dan keadaan si pembuat.

\section{Sistem Pemidanaan Dalam Undang- Undang No.11 Tahun 2012 tentang Sistem Peradilan Pidana Anak}

Jika pemberian pidana atau penjatuhan pidana diartikan sebagai pemidanaan, maka sistem pemidanaan

4 Sudarto, 1986, Kapita Selekta Hukum Pidana, Bandung: Alumni, hlm. 74.

5 Ibid, hlm. 78 
dalam tulisan ini adalah: keseluruhan system (perundang-undangan) yang mengatur bagaimana hokum pidana itu ditegakkan atau dioperasionalkan secara konkrit sehingga seseorang dijatuhi sanksi (hukum) pidana. ${ }^{6}$

Sistem pemidanaan dalam UndangUndang No 11 Tahun 2012, untuk menentukan pemidanaan selalu dibebankan kepada pelaku yaitu orang. Konsep pemidanaan yang berorientasi pada orang atau konsep pemidanaan individual/ personal ini lebih mengutamakan filsafat pembinaan/perawatan si pelaku kejahatan. Siapa yang berbuat dia yang bertanggung jawab. Dalam Undang-Undang No.11 Tahun 2012, sistem pertanggungjawaban pidananya bersifat individual/personal yang dibatasi oleh umur. Hal ini tertuang dalam Pasal 1 Undang-Undang No. 11 Tahun 2012, yang berbunyi: “Anak yang berkonflik dengan hukum yang selanjutnya disebut anak adalah anak yang telah berumur 12 (dua belas) tahun, tetapi belum berumur 18 (delapan belas) tahun yang diduga melakukan tindak pidana". Ini dapat dimaknai bahwa anak yang dapat dipertanggungjawabkan adalah anak yang melakukan tindak pidana yang telah berumur 12 (dua belas) tahun, tetapi belum berumur 18 (delapan belas) tahun.Apabila perbuatannya terbukti sebagai tindak pidana sesuai dengan yang didakwakan padanya dan terbukti kesalahannya maka teradap anak tersebut dapat dikenai pidana.

Dalam Undang-Undang Sistem Peradilan Pidana anak, walaupun batas umur ditentukan orang yang telah berumur 12 (dua belas) tahun, tetapi belum berumur 18 (delapan belas) tahun, namun terdapat pengaturan-pengaturan yang berbeda dalam sistem pemidanaannya yang diatur lebih lanjut dalam Pasal 21, dan Pasal 32 ayat (2) dan Pasal 69 ayat (2).

6 Barda Nawawi Arief, 2011, Perkembangan Sistem Pemidanaan Di Indonesia, Semarang: Pustaka Magister, hlm. 2.
Pasal 21 berbunyi: Dalam hal anak belum berumur 12 (dua belas) tahun melakukan atau diduga melakukan tindak pidana, penyidik, pembimbing kemasyarakatan, dan pekerja sosial profesional mengambil keputusan untuk: (a) menyerahkannya kembali kepada orang tua/wali; atau (b) mengikutsertakannya dalam program pendidikan, pembinaan, dan pembimbingan di instansi pemerintah atau LPKS (Lembaga Penempatan Anak Sementara) di instansi yang menangani bidang kesejahteraaan sosial, baik di tingkat pusat maupun daerah, paling lama 6 (enam) bulan.

Pasal 69 ayat (2) berbunyi: anak yang belum berusia 14 (empat belas) tahun hanya dapat dikenai tindakan; Ini berarti anak yang telah berusia 14 tahun dapat dikenai pidana.

Pasal 32 ayat (2) berbunyi: Penahanan terhadap anak hanya dapat dilakukan dengan syarat: (a) anak telah berumur 14 (empat belas) tahun atau lebih; dan (b) diduga melakukan tindak pidana dengan ancaman pidana penjara 7 (tujuh) tahun atau lebih.

Di Inggris, batas usia pertanggung jawaban (the age of responsibility) diatur sebagai berikut: Di bawah 10 tahun dipandang tidak mampu dalam melakukan kejahatan (incapable of crime atau doli incapax), sehingga tidak dapat dinyatakan bersalah atau dipidana. (Pasal 50 Children and Young Person Act 1933 sebagaimana diubah oleh Pasal 16 Children and Youang Person Act 1963); Umur 10 tahun tetapi di bawah 14 tahun, dipandang doli incapax, tetapi anggapan ini dapat dibantah dengan membuktikan adanya kehendak jahat (mischievous discretion) yaitu ia mengetahui bahwa apa yang dilakukannya adalah salah, sehingga apabila dia memiliki kehendak jahat dan mengetahui bahwa apa yang dilakukannya salah maka dipandang bertanggung jawab atas perbuatan yang 
dilakukannya; Di atas 14 tahun, kelompok usia ini sepenuhnya dipandang ber tanggungjawab atas perbuatan yang

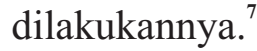

Dalam KUHP Korea, batas usia minimal untuk dapat dipertanggung jawabkan pidana, adalah 14 tahun. Sebagaimana juga dipakai di Jepang dan Norwegia. Dalam Article 9 The Corean Criminal Code, dinyatakan bahwa seseorang yang berusia di bawah 14 tahun tidak dapat dipidana atas perbuatan pidana yang dilakukannya. Section 46 The Norwegian Penal Code menyatakan, tidak seorangpun dapat dipidana atas perbuatan yang dilakukannya sebelum memenuhi usia 14 tahun. Begitu juga di dalam Article 41 Criminal Statute, dinyatakan bahwa perbuatan seseorang yang berumur 14 tahun tidak dipidana. ${ }^{8} \mathrm{Hal}$ ini sama dengan di Indonesia.

Ketentuan mengenai batasan umur yang demikian ini juga diatur dalam Rancangan Undang-Undang tentang Kitab Undang-Undang Hukum Pidana tahun 2015, Pasal 115 ayat (1), yang berbunyi: anak yang belum mencapai umur 12 (dua belas) tahun melakukan tindak pidana tidak dapat dipertanggungjawabkan.

Di dalam SMRJJ, dalam Rule 4.1 tidak ditetapkan batas usia minimum untuk dapat dipertanggungjawabkan seorang anak, karena menurut SMRJJ, the minimum age of criminal responsibility ini sangat berbeda-beda di antara negara-negara di dunia, bergantung pada latar belakang sejarah dan kebudayaannya maing-masing. Oleh karena itu Rule 4.1 menegaskan, bahwa di dalam sistem hukum yang mengenal batas usia pertanggungjawaban bagi anak, permulaan batas usia

7 Barda Nawawi Arief, 2013, Perbandingan Hukum Pidana, Jakarta: Raja Grafindo Persada, hlm.83.

8 Nandang Sambas, 2010, Pembaruan sistem Pemidanaan Anak di Indonesia, Yogyakarta: Graha Ilmu, hlm. 204. pertanggungjawaban itu janganlah ditetap kan terlalu rendah dengan mengingat faktor kematangan emosional, mental dan intelektualitas anak.

SMRJJ menghendaki adanya batas usia minimal yang beralasan (a reasonable lowest age limit). Dijelaskan dalam Commentary, bahwa berdasarkan pendekatan modern seorang anak dipertanggungjawabkan atas perbuatannya harus berdasarkan tingkat kecerdasan dan pemahaman individual dari anak itu. Oleh karena itu apabila batas usia pertanggung jawaban ditetapkan terlalu rendah atau sama sekali tidak ditentukan, maka konsepsi pertanggungjawaban akan menjadi tidak berarti (If the age of criminal responsibility is fixed too low or if there is no lower age limit at all, the notion of responsibility would become meaningless).

Ketentuan sanksi (pidana dan tindakan) bagi anak ini juga tertuang dalam SMRJJ (diadopsi melalui Resolusi Majelis Umum PBB 40/33) dan The Tokyo Rule tentang United Nations Standart Minimum Rules for Non-custodial Measures (diadopsi melalui Resolusi Majelis Umum PBB 45/110 tanggal 14 Desember 1990).

Ketentuan sanksi terhadap anak dalam SMRJJ, terdapat dalam Rule 18 tentang berbagai tindakan penempatan anak (various disposition measures). Di dalam Rule 18 ditegaskan berbagai bentuk tindakan penempatan anak, dimana satu sama lain kemungkinan dapat dikombinasikan, yaitu:

a. Care, guidance and supervision orders (perintah pengasuhan, pembimbingan dan pengawasan).

b. Probation(masa percobaan).

c. Community service orders (perintah pelayanan masyarakat).

d. Financial Penalties, compensation and restitution (sanksi finansial, kompen sasi dan restitusi).

e. Intermediate treatment and other 
treatment orders (perintah untuk pembinaan langsung atau tindakan pembinaan lain).

f. Orders to participate in group counseling and similar activities (perintah untuk berperan serta dalam kelompok konseling dan tindakan serupa).

g. Orders concerning foster care, living communities or other educational settings (perintah pembimbingan masyarakat, hidup di tengah masyarakat, tindakan pendidikan lain).

$h$. Other relevant orders (perintah relevan yang lain). ${ }^{9}$

Sanksi terhadap anak berdasarkan United Nations Standart Minimum Rules for Non-custodial Measures (The Tokyo Rule), diatur dalam Rule 8 tentang Sentensing disposition. Rule 8.1 mengatur bahwa pejabat Pengadilan berwenang di dalam menetapkan sanksi non custodial yang beragam dengan mempertimbangkan: (a) Kebutuhan pembinaan pelaku; (b) Perlindungan masyarakat dan kepentingan korban, sedangkan Rule 8.2 mengatur tentang pejabat pembinaan dapat saja menetapkan berbagai jenis sanksi yang berupa:

a. Sanksi verbal yang berupa pemberian nasihat baik (admonition), teguran keras/pencercaan (reprimand) dan peringatan keras (warning).

b. Pembebasan / pelepasan bersyarat (conditional discharge).

c. Pidana yang berhubungan dengan status (status penalties).

d. Sanksi ekonomi dan pidana yang bersifat uang seperti denda dan denda harian (economic sanction and monetary penalties, such as fine and dayfines).

e. Perampasan (confiscation) dan perintah

9 Setya Wahyudi, 2011, Implementasi Ide Diversi Dalam Pembaruan Sistem Peradilan Pidana Anak Di Indonesia, Yogyakarta: Genta, hlm.48. pengambilalihan (expropriation orders).

f. Pembayaran ganti rugi korban atau perintah kompensasi lain (restitution to the victim or a compensation orders).

g. Pidana bersyarat/tertunda (suspended and deferred sentence)

h. Pidana Pengawasan (probation and judicial supervision)

i. Perintah kerja sosial (community service order).

j. Pengiriman pada pusat kehadiran (referral to an attendance center).

k. Penahanan rumah (house arrest).

1. Pembinaan non lembaga lain (any other mode of non institutional treatment).

m. Dan kombinasi dari tindakan-tindakan di atas (some combination of the measures listed above). ${ }^{\mathbf{1 0}}$

Sanksi terhadap anak berdasarkan SMRJJdanUnited Nations Standart Minimum Rules for Non-custodial Measures (The Tokyo Rule), hampir sama yaitu terdapat pidana pengawasan, pidana percobaan, lepas bersyarat, kerja sosial, ganti rugi, denda, dan pembinaan di luar lembaga. Bila dibandingkan dengan di Indonesia dalam Undang-Undang No. 11 Tahun 2012 tentang Sistem Peradilan Pidana Anak, maka sanksi yang dapat dijatuhkan terhadap anak, pidana denda dan ganti rugi tidak terdapat. Pidana denda terhadap anak diganti dengan pidana latihan kerja.

\section{Penerapan sanksi Pidana Terhadap Anak Pelaku Tindak Pidana}

Menurut Pasal 71 (1), pidana yang dapat dijatuhkan terhadap anak terdiri dari : Pidana pokok yaitu:

a. Pidana peringatan;

b. Pidana dengan syarat:

1) Pembinaan di luar lembaga;

10 Ibid, hlm.49. 
2) Pelayanan masyarakat; atau

3) Pengawasan.

c. Pelatihan kerja;

d. Pembinaan dalam lembaga; dan

e. Penjara.

1) Pidana tambahan:

a) Perampasan keuntungan yang diperoleh dari tindak pidana; atau

b) Pemenuhan kewajiban adat.

2) Apabila dalam hukum materiil diancam pidana kumulatif berupa penjara dan dena, pidana denda diganti dengan pelatihan kerja.

3) Pidana yang dijatuhkan kepada anak dilarang melanggar hakat dan martabat anak.

4) Ketentuan lebih lanjut mengenai bentuk dan tata cara pelaksanaan pidana sebagaimana dimaksud pada ayat (1), ayat (2), dan ayat (3) diatur dengan Peraturan Pemerintah.

Ketentuan dalam Pasal 71 ayat (3) Undang-Undang Sistem Peradilan Anak, ini diatur lebih lanjut dalam Peraturan Menteri Hukum dan Hak Asasi Manusia No. 21 Tahun 2016 tentang Perubahan Atas Peraturan Menteri Hukum dan Hak Asasi Manusia No.21 Tahun 2013 tentang Syaratsyarat dan Tata Cara Pemberian Remisi, Asimilasi, Cuti Mengunjungi Keluarga, Pembebasan Bersyarat, Cuti Menjelang Bebas, dan Cuti Bersyarat. Pasal 49 A, mengatur dalam hal anak dijatuhi pidana kumulatif berupa pidana penjara dan pidana denda, pidana denda diganti dengan pelatihan kerja. Pelatihan kerja tidak dilaksanakan oleh kementerian Hukum dan HAM melainkan Kementerian lain. Yang dimaksud dengan "lembaga yang melaksanakan pelatihan kerja" diatur dalam penjelasan Pasal 78 ayat (1), yaitu antara lain balai latihan kerja, lembaga pendidikan vokasi yang dilaksanakan, misalnya oleh kementerian yang menyelenggarakan urusan pemerintahan di bidang ketenagakerjaan, pendidikan atau sosial.
Menurut Pasal 49 B Peraturan Menteri Hukum dan Hak Asasi Manusia No. 21 Tahun 2016, anak yang memperoleh pembebasan bersyarat dapat terlebih dahulu melaksanakan pelatihan kerja sebelum menjalani pembebasan bersyarat.

Menurut Pasal 49 C, selama anak menjalani pelatihan kerja pengganti pidana denda, anak tinggal bersama orang tua/wali, lembaga sosial, atau lembaga lain yang ditunjuk.

Menurut Pasal 78, pidana pelatihan kerja dilaksanakan di lembaga yang melaksanakan pelatihan kerja yang sesuai dengan usia anak, paling singkat 3 bulan paling lama 1 tahun.

Dalam praktik, ketentuan Pasal 71 ayat (3) Undang-Undang Sistem Peradilan Anak, yang menyatakan bahwa: apabila dalam hukum materiil diancam pidana kumulatif berupa pidana penjara dan denda, pidana denda dapat diganti dengan pelatihan kerja, ternyata tidak selalu dijatuhkan pidana pelatihan kerja, melainkan oleh hakim dijatuhkan pidana pembinaan dalam lembaga. Hakim tidak selalu memutus berdasar ancaman yang terdapat dalam hukum pidana materiil, melainkan hakim memutus di luar ancaman dalam hukum pidana materiil, dalam hal ini ancaman pidana penjara dan pelatiham kerja tidak dijatuhkan melainkan dijatuhkan pidana pembinaan dalam lembaga yang memang merupakan jenis pidana yang diatur dalam Pasal 71 UndangUndang Sistem Peradilan Pidana Anak.

Pidana pembinaan dalam lembaga diatur dalam Pasal 80, dinyatakan bahwa: Pembinaan di dalam lembaga dilakukan di tempat pelatihan kerja atau lembaga pembinaan yang diselenggarakan baik oleh pemerintah maupun swasta. Pidana pembinaan di dalam lembaga dijatuhkan apabila keadaan dan perbuatan anak tidak membahayakan masyarakat. Pembinaan dalam lembaga dilaksanakan paling singkat 3 (tiga) bulan dan paling lama 24 (dua puluh empat) bulan. Anak yang telah menjalani 1/2 
(satu perdua) dari lamanya pembinaan di dalam lembaga dan tidak kurang dari 3 (tiga) bulan berkelakuan baik berhak mendapatkan pembebasan bersyarat.

Berikut contoh perkara anak yang dipidana dengan pidana pembinaan di dalam lembaga:

1. Putusan Hakim Pengadilan Negeri Kendal, perkara No.1/Pid.SusAnak/2015/PN Kendal, terhadap terdakwa (Aditya Ardi Wijaya bin Sukardi), terbukti melanggar Pasal Pasal 76 E Jo Pasal 82 ayat (1) Undang-Undang No.35 Tahun 2014, yang bunyinya: Setiap orang dilarang melakukan kekerasan atau ancaman kekerasan, memaksa, melakukan tipu muslihat, melakukan serangkaian kebohongan, atau membujuk anak melakukan atau membiarkan dilaku kan perbuatan cabul, diancam dengan pidana penjara paling singkat 5 (lima) tahun dan paling lama 15 (lima belas) tahun dan denda paling banyak Rp. 5.000.000.000 (lima miliar rupiah). Hakim yang menangani perkara ini menjatuhkan pidana terhadap terdakwa berupa pidana pembinaan dalam lembaga, yaitu dimasukkan ke Panti Sosial Marsudi Putra Antasena Magelang untuk menjalani pembinaan atau pembimbingan selama jangka waktu 14 (empat belas) bulan.

Hakim berpendapat bahwa terhadap terdakwa lebih tepat untuk ditempatkan pada pembinaan dalam lembaga, yang dalam hal ini adalah dimasukkan ke Panti Sosial Marsudi Putra Antasena Magelang, karena anak tersebut memiliki potensi untuk menjadi anak yang baik, sehingga perlu diberikan bimbingan dan rehabilitasi sosial dari pihak-pihak terkait yang berkompeten sehingga tumbuh kembang nya dapat secara maksimal dan harmonis. Dengan memperhatikan kepentingan terbaik bagi anak, maka anak tersebut perlu mendapatkan bimbingan menyeluruh, berupa bimbingan fisik dan kesehatan, bimbingan mental, psikologi, agama dan kecerdasan, bimbingan sosial, konseling, terapi serta ketrampilan kerja. ${ }^{11}$

2. Putusan Hakim Pengadilan Negeri Kendal, perkara No. 4/Pid.Sus.Anak/ 2015/PN Kendal.

Terhadap terdakwa (Ahmad Hasbullah Maulana Als Tana Als Nyuk bin Sutrisno dan Khoirul Mita Als Mita Als Macan bin Sifa'udin), terbukti melakukan tindak pidana melanggar Pasal 76 E Jo Pasal 82 ayat (1) Undang-Undang No.35 Tahun 2014, yang bunyinya: Setiap orang dilarang melakukan kekerasan atau ancaman kekerasan, memaksa, melakukan tipu muslihat, melakukan serangkaian kebohongan, atau membujuk anak melakukan atau membiarkan dilakukan perbuatan cabul, diancam dengan pidana penjara paling singkat 5 (lima) tahun dan paling lama 15 (lima belas) tahun dan denda paling banyak Rp. 5.000.000.000 (lima miliar rupiah). Hakim yang menangani perkara ini menjatuhkan pidana terhadap terdakwa berupa pidana pembinaan dalam lembaga, yaitu dimasukkan ke Panti Sosial Marsudi Putra Antasena Magelang untuk menjalani pembinaan/pembimbingan selama jangka waktu 15 (lima belas) bulan .

Hakim berpendapat bahwa terhadap terdakwa lebih tepat untuk ditempatkan pada pembinaan dalam lembaga yang dalam hal ini adalah dimasukkan ke Panti Sosial Marsudi Putra Antasena Magelang, karena merupakan unit pelaksana teknis dari Kementerian Sosial yang fokus untuk memberikan pembinaan/bimbingan kepada anak yang berhadapan/berkonflik dengan hukum yang salah satunya memberikan manfaat bimbingan fisik dan kesehatan, bimbingan mental, psikologi, agama dan kecerdasan, bimbingan social, konseling dan terapi serta ketrampilan kerja. Selain itu Panti Sosial Marsudi Putra Antasena Magelang, juga memberikan rehabilitasi sosial yang bersifat preventif, kuratif,

11 Pertimbangan Hakim dalam Putusan perkara No. 4/Pid.Sus.Anak/2015/PN Kendal. 
rehabilitatif, promotif dalam bentuk bimbingan fisik, mental, sosial, serta bimbingan lebih lanjut bagi anak yang berperilaku menyimpang agar mampu memperbaiki dirinya untuk ke depannya, sehingga dengan demikian hakim berpendapat bahwa dengan menempatkan para terdakwa yang masih berstatus anak tersebut pada pembinaan dalam lembaga adalah merupakan hal yang terbaik bagi kepentingan para terdakwa untuk ke depannya. Selain dari itu, Hakim berpendapat bahwa tujuan pemidanaan di atas, bukanlah semata-mata untuk membalas dendam atas perbuatan pidana yang telah dilakukan oleh anak, akan tetapi juga bersifat edukatif yaitu instrumen pembelajaran bagi anak, agar dapat memperbaiki sikap dan perbuatannya di masa yang akan datang, sekaligus juga sebagai instrumen intimidasi yang efektif agar anggota masyarakat diharapkan tidak melakukan perbuatan pidana sebagaimana yang dilakukan oleh terdakwa. ${ }^{12}$

Dalam ke dua contoh kasus tersebut, Hakim tidak selalu memutus berdasar ancaman yang terdapat dalam hukum pidana materiil, melainkan hakim memutus di luar ancaman dalam hukum pidana materiil, dalam hal ini ancaman pidana penjara dan pelatiham kerja tidak dijatuhkan melainkan dijatuhkan pidana pembinaan dalam lembaga yang memang merupakan jenis pidana yang diatur dalam Pasal 71 Undang-Undang Sistem Peradilan PidanaAnak.

Hakim, dalam perkara ini, telah melakukan terobosan hukum dengan pertimbangan bahwa menempatkan para terdakwa yang masih berstatus anak tersebut pada pembinaan dalam lembaga adalah merupakan hal yang terbaik bagi kepentingan terbaik bagi anak, dari pada memidana penjara. Selain dari itu, Hakim berpendapat bahwa tujuan pemidanaan di

12 Pertimbangan Hakim dalam Putusan Perkara No. 4/Pid.Sus.Anak/2015/PN Kendal. atas, bukanlah semata-mata untuk membalas dendam atas perbuatan pidana yang telah dilakukan oleh anak, akan tetapi juga bersifat edukatif yaitu instrumen pembelajaran bagi anak, agar dapat memperbaiki sikap dan perbuatannya di masa yang akan datang. Terobosan hukum ini menurut penulis, bisa dikatakan bahwa hakim telah keluar dari positivisme hukum menuju ke progresivisme. Progresivisme menurut Satjipto Rahardjo bertolak dari pandangan kemanusiaan, manusia pada dasarnya adalah baik, memiliki sifat-sifat kasih sayang serta kepedulian terhadap sesama. Hal tersebut menjadi modal penting untuk membangun kehidupan berhukum dalam masyarakat. Dengan demikian, hukum menjadi alat untuk menjabarkan dasar kemanusiaan tersebut. Hukum bukan raja, tetapi alat saja yang berfungsi memberikan rahmat kepada dunia dan manusia. Hukum mempunyai tujuan besar berupa kesejahteraan dan kebahagiaan manusia, maka hukum selalu berada pada status 'law in the making'. Hukum tidak ada untuk dirinya sendiri dan tidak bersifat final. Setiap tahap dalam perjalanan hukum adalah putusan-putusan yang dibuat guna mencapai ideal hukum, baik dibuat oleh legislatif, yudikatif, maupun eksekutif. ${ }^{13}$

Menurut Satjipto Rahardjo, kata kunci dalam gagasan hukum progresif adalah kesediaan untuk membebaskan diri dari faham status quo. Ide tentang pembebasan diri tersebut berkaitan erat dengan faktor psikologis atau spirit yang ada dalam diri para pelaku (aktor) hukum, yaitu keberanian (dare). Masuknya faktor keberanian tersebut memperluas peta cara berhukum, yaitu yang tidak hanya mengedepankan aturan (rule), tetapi juga perilaku (behavior). Berhukum menjadi tidak hanya tekstual, melainkan juga melibatkan predisposisi personal. ${ }^{14}$

13 Satjipto Rahardjo, 2009, Hukum Progresif, ebuah Sintesa Hukum Indonesia, Yogyakarta: Genta, hlm. 17-18. 14 Ibid, hlm.91. 
Dalam dua perkara di atas, apabila dianalisa dengan tiga nilai dasar dari Gustaf Radbruch, mengenai nilai keadilan, kemanfaatan dan kepastian hukum, maka hakim memutus lebih kepada nilai kemanfaatan dari pidana yang dijatuhkan, dengan menjatuhkan pidana pembinaan dalam lembaga lebih bermanfaat bagi terdakwa dari pada pidana penjara.

3. Putusan Hakim Pengadilan Negeri Kendal, perkara Nomor: 1/Pid.SUS. Anak/2016/PN.Kdl, dan Nomor : 2/Pid.SUS. Anak/2016/PN.Kdl.

Putusan Nomor: 1/Pid.SUS.Anak /2016/PN.Kdl, memutuskan terhadap terdakwa Chairul Umam Bin Tasriyono, umur 12 tahun 10 bulan, pelajar kelas I SMP,Putusan Nomor: 2/Pid.SUS.Anak /2016/PN.Kdl, memutuskan terhadap terdakwa Ajib Darmawan Bin Mujian, umur 12 tahun 5 bulan, pelajar Kelas I SMP, Keduanya terbukti melanggar Pasal 76 E Jo Pasal 82 ayat (1) Undang-Undang No.35 Tahun 2014, dengan korban Anggrayni Adinda Ramdhani Binti Andy Sasongko anak berusia 7 tahun.

Pasal 76 E berbunyi: Setiap orang dilarang melakukan kekerasan atau ancaman kekerasan, memaksa, melakukan tipu muslihat, melakukan serangkaian kebohongan, atau membujuk anak melakukan atau membiarkan dilakukan perbuatan cabul. Pasal 82 ayat (1) berbunyi: Setiap orang yang melanggar ketentuan sebagaimana dimaksud dalam Pasal $76 \mathrm{E}$ dipidana dengan pidana penjara paling singkat 5 (lima) tahun dan paling lama 15 (lima belas) tahun dan denda paling banyak Rp. 5.000.000.000 (lima miliar rupiah).

Hakim yang menangani perkara ini menjatuhkan pidana terhadap terdakwa Chairul Umam Bin Tasriyono dengan pidana penjara selama 3 tahun 6 bulan, di LPKA Kutoarjo, serta menetapkan agar anak menjalani pelatihan kerja pada lembaga pelatihan kerja selama 6 (enam) bulan.Sedangkan terhadap terdakwa Ajib Darmawan Bin Mujian,dipidana penjara selama 2 (dua) tahun dan 6 (enam) bulandi LPKA Kutoarjo dan menetapkan agar anak menjalani pelatihan kerja pada lembaga pelatihan kerja selama 3 (tiga) bulan Perbuatan terdakwa terbukti Dengan Sengaja Mengancam Anak untuk melakukan beberapa Perbuatan Cabul yang dipandang sebagai perbuatan berlanjut.

Pertimbangan hakim menjatuhkan pidana penjara terhadap anak yang belum berumur 14 tahun tersebut adalah sebagai berikut: perbuatan yang telah dilakukan oleh terdakwa adalah perbuatan yang tidak dapat dikategorikan sebagai perbuatan yang ringan, karena melakukan peng ancaman terhadap Anak untuk kemudian sang anak/terdakwa melakukan perbuatan Cabul terhadap korban yang masih berusia 7 (tujuh) tahun, menurut pendapat Majelis Hakim adalah merupakan perbuatan kejahatan yang kategorinya berat, yang efeknya akan sangat menimbulkan kerugian yang besar baik fisik maupun mental/psikis terhadap korban, dan tentu saja sangat meresahkan masyarakat pada umumnya.Perbuatan cabul terhadap Anak Bagi Majelis Hakim merupakan tindak pidana yang serius atau dapat diklasifikasi kan sebagai tindak pidana berat, sehingga haruslah diberikan sanksi yang tegas dan berat agar tindak pidana tersebut tidak terulang lagi dimasa yang akan datang, yang efek dari pemidanaan tersebut tidak hanya terfokus/tertuju pada pelaku semata, namun pada orang-orang lain/masyarakat sekitar, agar tidak melakukan perbuatan yang keji tersebut. ${ }^{15}$

Majelis Hakim berpendapat bahwa pelaku Anak tersebut, tidaklah tepat untuk diterapkan tindakan sebagaimana Pasal 82 Undang-Undang No 11 Tahun 2012 tentang Sistem Peradilan Pidana Anak, namun demi untuk kelangsungan masa depan anak, memperbaiki moral/spiritual dan aspek religius sang Anak, Majelis Hakim

15 Pertimbangan Hakim dalam Putusan perkara No. 1/Pid.SUS.Anak/2016/PN.Kdl, dan Nomor: 2/Pid.SUS.Anak/2016/PN.Kdl. 
berpendapat lebih tepat untuk diberikan pidana penjara. Pidana Penjara yang akan diterapkan kepada Pelaku, akan dapat memberikan pembinaan yang maksimal terhadap pelaku Anak, sehingga Pelaku anak dapat memperbaiki akhlak dan perbuatannya, budi pekertinya, aspek religiusnya yang pada akhirnya sang anak benar-benar memahami bahwa perbuatan nya yang telah dilakukan dahulu adalah keliru, tidak benar, melanggar ketentuan Agama, melanggar ketentuan UndangUndang tentang Perlindungan Anak, Majelis Hakim didalam menerapkan penjatuhan Pidana berupa Pidana Penjara terhadap anak tidak hanya memperhatikan kepentingan sang anak sebagai Pelaku, tetapi juga memperhatikan kepentingan anak yang menjadi korban tindak pidana. Kepentingan Korban tindak Pidana yang masih berusia 7 Tahun, menurut pendapat Majelis Hakim haruslah juga ikut diperhatikan, karena anak korbanlah yang sebenarnya paling menderita, paling tersiksa terhadap perbuatan yang telah dilakukan oleh pelaku, sehingga penerapan pidana berupa pidana penjara yang diterapkan terhadap Pelaku anak, setidaknya akan memberikan pembelajaran atau warning bagi sang anak Choirul Umam dan Ajib Darmawan, juga anak-anak lainnya/warga masyarakat pada umumnya, untuk tidak melakukan perbuatan sebagaimana yang telah dilakukan oleh sang Anak. Menurut pendapat Majelis Hakim, LPKA Kutoarjo merupakan Lembaga Pembinaan khusus Anak, lembaga tersebut, akan dapat memberikan pembinaan yang terbaik bagi Anak / terdakwa Choirul Umam, karena anak akan mendapatkan pembinaan yang komprehensif yang meliputi pembinaan keagamaan/budi pekerti, kesadaran berbangsa dan bernegara, pendidikan umum (kejar paket A,B,C), kesegaran jasmani dan kesenian, pelayanan kesehatan dan latihan ketrampilan, sehingga diharap kan setelah selesai menjalani pembinaan pada LPKA tersebut, anak atau terdakwa Choirul Umam dan Ajib Darmawan, dapat memperbaiki dan meningkatkan akhlak (budi pekerti), memantapkan iman (ketahanan mental), serta dapat berintegrasi secara wajar dalam kehidupan ber masyarakat pada umumnya.

Selain itu, Majelis Hakim berpendapat bahwa tujuan pemidanaan berupa pidana penjara tersebut, bukanlah semata-mata untuk membalas dendam atas perbuatan pidana yang telah dilakukan oleh anak, akan tetapi juga bersifat edukatif yaitu instrumen pembelajaran bagi anak, agar dapat memperbaiki sikap dan perbuatannya di masa yang akan datang, sekaligus juga sebagai instrumen intimidasi yang efektif agar anggota masyarakat diharapkan tidak melakukan perbuatan pidana sebagaimana yang dilakukan oleh anak.

Kasus tersebut di atas menunjukkan bahwa Pasal 69 ayat (2) Undang-Undang No 11 Tahun 2012 tentang Sistem Peradilan Pidana Anak, yang mengatur bahwa anak yang belum berusia 14 (empat belas) tahun hanya dapat dikenai tindakan, dalam praktiknya tidak selalu diterapkan oleh Hakim.

Dari tiga perkara anak yang telah mendapat vonis hakim tersebut, nampak bahwa penerapan sanksi pidana yang dijatuhkan oleh hakim terhadap anak pelaku tindak pidana tidak selalu sama dengan ancaman yang terdapat dalam pasal yang didakwakan oleh penuntut umum, sekalipun perbuatannya memenuhi rumusan delik, namun jenis pidananya hakim menjatuhkan berdasarkan keyakinan hakim dan memiliki rasio decidendi atau reasoningyaitu pertimbangan hakim untuk sampai pada suatu putusan, yang berbeda antara majelis hakim yang satu dengan majelis hakim yang lain. 


\section{Pertimbangan Hakim Sebelum Menerapkan Sanksi Pidana Terhadap Anak Pelaku Tindak Pidana}

Hakim sebelum memutus suatu perkara harus mempertimbangkan beberapa hal terkait dengan perkara yang diadili, selain mempertimbangkan fakta perbuatan, ketentuan yuridis, hal-hal yang memberatkan dan yang meringankan, hakim juga mempunyai pertimbangan yang subyektif terhadap pelaku yang diadilinya berdasarkan hasil pembuktian di persidangan.

Pengemban hukum praktis yang menjadi tulang punggung kegiatan penalaran hukum adalah hakim. Menurut Mochtar Kusumaatmadja dan B. Arief Sidharta:

Lembaga peradilan mempunyai kedudukan penting dalam system hokum Indonesia karena ia melakukan fungsi yang pada hakikatnya melengkapi ketentuanketentuan hokum tertulis melalui pembentukan hokum (rechts vorming) dan penemuan hukum (rechtsvinding). Dengan perkataan lain, hakim dalam system hukum Indonesia yang pada dasarnya bersifat tertulis itu mempunyai fungsi membuat hukum baru (creation of new law). ${ }^{16}$

Menurut Sri Sutatiek, berdasarkan hasil penelitiannya sewaktu melakukan wawancara dengan Ketua Pengadilan Negeri Semarang, Bahwa:

Putusan hakim selain dipengaruhi oleh pertimbangan-pertimbangan yuridis, juga terdapat pertimbangan non yuridis, yaitu aspek sosiologis, psikologis, etika, dan historis dari anak. Tuntutan jaksa juga mempengaruhi hakim dalam membuat putusan hakim, namun

16 Shidarta, 2013, Hukum Penalaran dan Penalaran Hukum, Yogyakarta: Genta Publishing, hlm.288. hakim tetap mempunyai kemerdekaan untuk menentukan putusan berdasarkan pertimbanganpertimbangan tertentu.Dalam praktik, meskipun jaksa menuntut anak dengan pidana penjara, hakim dapat pula menjatuhkan bukan pidana penjara. ${ }^{17}$

Hal ini terlihat dalam perkara No. 4/Pid.Sus.Anak/2015/ PN Kendal, dan perkara No. 4/Pid.Sus.Anak/2015/PN Kendal, hakim tidak menjatuhkan pidana penjara dan denda seperti yang tertera dalam rumusan pasal yang dilanggar, melainkan hakim menjatuhkan pidana pembinaan di dalam lembaga, dengan pertimbangan demi masa depan anak supaya lebih baik.

Demikian pula dalam perkara Nomor:1/Pid.SUS.Anak/2016/PN.Kdl, dan Nomor:2/Pid.SUS.Anak/2016/ PN.Kdl, nampak bahwa hakim tidak menjatuhkan tindakan kepada anak yang belum berumur 14 tahun, sesuai ketentuan Pasal 69 ayat (2), melainkan menjatuhkan pidana penjara. Ini menunjukkan bahwa dalam praktik ternyata rumusan sanksi pidana yang tertera dalam pasal yang terbukti di persidangan ternyata tidak selalu diterapkan oleh hakim.

\section{Kesimpulan}

Penerapan sanksi pidana terhadap anakpelaku tindak pidana adalah Hakim mempunyai kebebasan untuk menetapkan jenis pidana, cara pelaksanaan pidana dan tinggi rendahnya pidana, Hakim dapat bergerak antara minimum pidana yang umum yang berlaku untuk semua delik dan maksimum pidana yang khusus untuk tiaptiap delik. Namun kebebasan ini tidak berarti bahwa hakim boleh menjatuhkan pidana menurut seleranya sendiri, tanpa

17 Sri Sutatiek, 2013, Rekonstruksi Sistem Sanksi Dalam Hukum Pidana Anak Di Indonesia Urgensi Penerbitan Panduan Pemidanaan (The Sentencing Guidelines) Untuk Hakim Anak, Yogyakarta: Aswaja Pressindo, hlm. 33. 
ukuran tertentu. Dalam keputusan hakim harus terbaca proses pemikiran yang dapat diikuti oleh orang lain, sehingga wajar bahwa dalam pemberian pidana inipun proses pemikirannya harus dapat diikuti oleh orang lain pula, utamanya terdakwa.

Pertimbangan hakim sebelum menerapkan sanksi pidana terhadap anak pelaku tindak pidana adalah selain mempertimbangkan fakta perbuatan, ketentuan yuridis, hal-hal yang memberat kan dan yang meringankan, hakim juga mempunyai pertimbangan yang subyektif terhadap pelaku yang diadilinya berdasar kan hasil pembuktian di persidangan. Putusan hakim selain dipengaruhi oleh pertimbangan-pertimbangan yuridis, juga terdapat pertimbangan non yuridis, yaitu aspek sosiologis, psikologis, etika, dan historis dari anak.

\section{DAFTAR PUSTAKA}

Barda Nawawi Arief, 2011, Perkembangan Sistem Pemidanaan Di Indonesia, Semarang: Pustaka Magister.

Hukum Pidana, Jakarta: Raja Grafindo Persada.

Nandang Sambas, 2010, Pembaruan sistem Pemidanaan Anak di Indonesia, Yogyakarta: Graha Ilmu.
Peter Mahmud Marzuki, 2006, Penelitian Hukum, Jakarta: Kencana Prenada Media Group.

Satjipto Rahardjo, 2009, Hukum Progresif, ebuah Sintesa Hukum Indonesia, Yogyakarta: Genta.

Setya Wahyudi, 2011, Implementasi Ide Diversi Dalam Pembaruan Sistem Peradilan Pidana Anak Di Indonesia, Yogyakarta: Genta.

Shidarta, 2013, Hukum Penalaran dan Penalaran Hukum, Yogyakarta: Genta Publishing.

Sri Sutatiek, 2013, Rekonstruksi Sistem Sanksi Dalam Hukum Pidana Anak Di Indonesia Urgensi Penerbitan Panduan Pemidanaan (The Sentencing Guidelines) Untuk Hakim Anak, Yogyakarta: Aswaja Pressindo.

Sudarto, 1983, Hukum dan Hukum Pidana, Bandung: Alumni.

---------, 1986, Kapita Selekta Hukum Pidana, Bandung: Alumni.

https://news.detik.com/berita/d-4128703/ ada-504-kasus-anak-jadi-pelakupidana-kpai-soroti-pengawasan-ortu, diakses tanggal 5 April 2019. 